\title{
THE IMPERATIVES OF THE DEVELOPMENT OF THE TOURIST SERVICES MARKET IN SPATIAL POLARIZATION OF THE REGIONAL TOURIST SYSTEM
}

\author{
Natalia V. TRUSOVA* \\ Tavria State Agrotechnological University, Department of Finance, \\ Banking and Insurance, Melitopol, Ukraine, e-mail: trusova_natalya5@ukr.net

\section{Yurii Y. KYRYLOV} \\ Kherson State Agrarian University, Department of Public Management \\ and Administration, Kherson, Ukraine, e-mail: kirilov_ye@ukr.net

\section{Viktoriia Hr. HRANOVSKA} \\ Kherson State Agrarian University, Department of Hotel and Restaurant \\ and Tourism Business, Kherson, Ukraine, e-mail: vgranovska@ukr.net

\section{Oleksandr S. PRYSTEMSKYI} \\ Kherson State Agrarian University, Department of Accounting and Taxation, \\ Kherson, Ukraine, e-mail: pristemskiyaleksandr@gmail.com

\section{Viktoriia M. KRYKUNOVA} \\ Kherson State Agrarian University, Department of Hotel and Restaurant \\ and Tourism Business, Kherson, Ukraine, e-mail: krykunova_vm@yahoo.com
}

\author{
Alina Zh. SAKUN \\ Kherson State Agrarian University, Department of \\ Accounting and Taxation, Kherson, Ukraine, e-mail: agorg@ukr.net
}

\begin{abstract}
Citation: Trusova, N.V., Kyrylov, Y.Y., Hranovska, V.Hr., Prystemskyi, O.S., Krykunova, V.M. \& Sakun, A.Zh. (2020). THE IMPERATIVES OF THE DEVELOPMENT OF THE TOURIST SERVICES MARKET IN SPATIAL POLARIZATION OF THE REGIONAL TOURIST SYSTEM. GeoJournal of Tourism and Geosites, 29(2), 565-582. https://doi.org/10.30892/gtg.29215-490
\end{abstract}

\begin{abstract}
The article deals with the imperatives of the development of the tourist services market, which determines the parameters of the aggregate value of the sub-indices of the meso- and local levels in the spatial polarization of the regional tourist system. The methodology of spatial polarization of the regional tourist system, which provides convergence of the infra-structural space of tourist services, formation of an innovative nucleus, minimization of manifestation of destructive factors, balancing of interests of regions and the country as a whole is substantiated. It has been proposed the scientific-methodical approach to the definition of the target landmarks for the development of the tourist services market, which implements polarized tourist space in terms of quantitative and qualitative parameters, makes it possible to analyze the destructive determinants of the periphery and determinants-producers of the tourist center of activity, evaluation
\end{abstract}

\footnotetext{
* Corresponding author
} 
Natalia V. TRUSOVA, Yurii Y. KYRYLOV, Viktoriia Hr. HRANOVSKA, Oleksandr S. PRYSTEMSKYI, Viktoriia M. KRYKUNOVA, Alina Zh. SAKUN

and forecasting of the safe level of the hierarchy of the regional tourist system, determination of clear impulses for the development of the tourist services market and density of interaction of the periphery with the center. Revenues from the sale of tourist services of local level enterprises have been analyzed. A comprehensive approach to the assessment of the concentration of the aggregate value of the security index of the regional tourist system, which is differentiated by the components of the regional security potential and threats, guarantees the development of the tourist services market and modifies the tourist system on the meso-level as a whole.

Key words: tourism revenues, tourism expenditures, tourism product, innovation potential, security index

\section{INTRODUCTION}

The development of the tourist market of states is based on the spatial, resource, production and consumer potentials of specific territories. Under favorable conditions and adequate levers of state support, the territories are capable of providing the increase in innovative capacity and are able to activate the regional tourist system, which is the main catalyst for the rise of socio-economic processes in the world. At the same time, the scale, dynamism, heterogeneity of tourist market development and transnationalization of tourism activity in the leading countries are predominantly elitist and have a significant impact on tourism in the periphery countries. It leads to uneven tourism demand in potentially identical tourist destinations, and the diverse impact of tourism on the socio-economic development of states leads to transformational shifts in the polarized regional system of the tourist market. Integrating international tourism processes and effective competing in the tourism market can only be done on the basis of exploiting all the possibilities of the regions, resources of the subjects of certain economic activities and spatial infrastructure of tourism, which largely depends on the doctrine of state development and targeted regional programs that generate innovative potential with a high level of technical and technological composition.

The study of the regional economy as an ontological and concrete component of social systems has been reflected in the works of Kocziszky et al. (2015), Timmer et al. (2019), Partridge (2017), Chen \& Zeng (2018), Wood et al. (2017), Brailly (2016), Brozovic (2020), Cosenz et al. (2020), Cano Guervos (2020). Theoretical and applied aspects of tourist services market development are widely studied by such scientists as: Khalid, et al. (2020), Gorban (2017), Guryanova \& Prokopovich (2013), Chi et al. (2020), Lohmatov (2011), Aleksushin et al. (2020), Spalding \& Parrett (2019), Moiseeva (2018). The processes of spatial organization and spatial polarization of the tourist services market were studied by Avramchikova (2018), Bhola-Paul (2015), Brandão et al. (2019), Kisswani et al. (2020), Gorina (2016), Majewska \& Truskolaski (2019), Krasavceva (2014), Maltseva (2016), Zarezadeh et al. (2019), Mitrofanov (2013), Çakmak et al. (2019).

Adoption of the axiom that the infrastructure components of the tourist services market, which change the parameters of functioning of certain spheres of economic activity is due to socio-economic, historical, cultural and geographical features of the meso-level, and their differentiated impact modernizes the process of preserving the potential of natural resources through innovative dominance, the level of potential of the regional tourist system. Therefore, there is an objective need to study the imperatives of the development of the tourist services market, which determine the 
The Imperatives of the Development of the Tourist Services

Market in Spatial Polarization of the Regional Tourist System

parameters of the aggregate value of the sub-indices of the meso- and local levels in the spatial polarization of the regional tourist system.

\section{METHODOLOGY}

Spatial polarization is an objective condition for the development of the tourist market, caused by differences in the distribution of natural resources, climatic features of the regions, cultural and historical conditionality and uneven placement of transport, communication, resort and recreational infrastructure, asymmetry of the distribution of resources. However, significant regional disproportion and spatial differentiation, uneven economic and social development of territorial entities lead to an imbalance between the economic growth rates of donor territories and recipient territories. Provision of polarization development of regions with the allocation and support of a network of powerful centers of local, regional and interregional levels is due, on the one hand, to the properties of natural resource potential, on the other hand, processes of financial, economic and political-legal character (Serrano et al., 2019).

In this regard, the development of the tourist services market, taking into account the polarizing aspects of the regional tourist system, is characterized by the presence of two parallel interrelated tendencies: on the one hand, the undoubted influence of the economic space (the environment of the existence of the regional tourist system) and the resources of the subjects of tourist services, on the other hand - the simultaneous spread of its active influence on the space of its functioning, through a complex of interconnected tourist subsystems, ordered by certain qualities of the system.

The methodology of spatial polarization of the regional tourist system implies convergence of the infrastructure space of tourist services, formation of an innovative nucleus, minimization of manifestation of destructive factors, balancing of interests of regions and the country as a whole. The heterogeneous spatial hierarchy of the regional tourist system in the form of a nucleus (center) of concentration of tourist activity determines the financial, investment, information and technological opportunities of the tourist services market and shapes the dynamics of tourist flows (revenues from tourism). The cumulative effect and dynamism of these factors leads to a change in the position of the nucleus and, accordingly, of the spatial framework of the tourist services market, thus transforming the relationship between the center and the periphery.

It should be noted that the hierarchy of centers of tourist space is the result of center-peripheral relations, which are manifested at all spatial levels in the following forms: the center and periphery of the world economy (macro-level), central and peripheral regions of regional (meso-level) and local (micro) levels. Spatially polarized regional system, which ensures the development of the tourist services market, substantiates the patterns of interaction between the nucleus and the periphery. The nucleus controls material, financial, innovation, information flows, applies new technologies and processes, possesses more sophisticated forms of work, is a "provider of intellectual resources", it generates innovation (Tolstoguzov, 2012). Thus, the constant dominance of the center over the periphery ensures the continuity of innovative activity: the center has the most intense and close contacts, better access to information.

The periphery has both an internal (near) spatial connection to the nucleus (directly receiving impulses to development), and an external or distant (deep) connection to which the nucleus has virtually no mobilizing effect. Center and periphery at any spatial level are interconnected flows of information, capital, goods and labor.

It is the direction of these flows that determine the nature of the interaction between the central and peripheral structures, transforming the space into a semblance 
Natalia V. TRUSOVA, Yurii Y. KYRYLOV, Viktoriia Hr. HRANOVSKA, Oleksandr S. PRYSTEMSKYI, Viktoriia M. KRYKUNOVA, Alina Zh. SAKUN

of a force field. Length and distance between the center and the periphery are important in the degree of power of influence and density of interaction.

The interaction of the nucleus and the periphery with the diffusion of innovations is seen as the process of expanding the territory covered by technical, technological, economic, environmental, social and other innovations. In a negative sense, this process is determined as a diffusion of outdated innovations, which contributes to a certain development of the periphery, but consolidates its subordinate position towards the center (Shablyj \& Soxaczka, 2012), which leads to the impulse to maintain uneven development. Schematically the interaction of the center and the periphery within the economic space of the regional tourist system is presented in Figure 1.
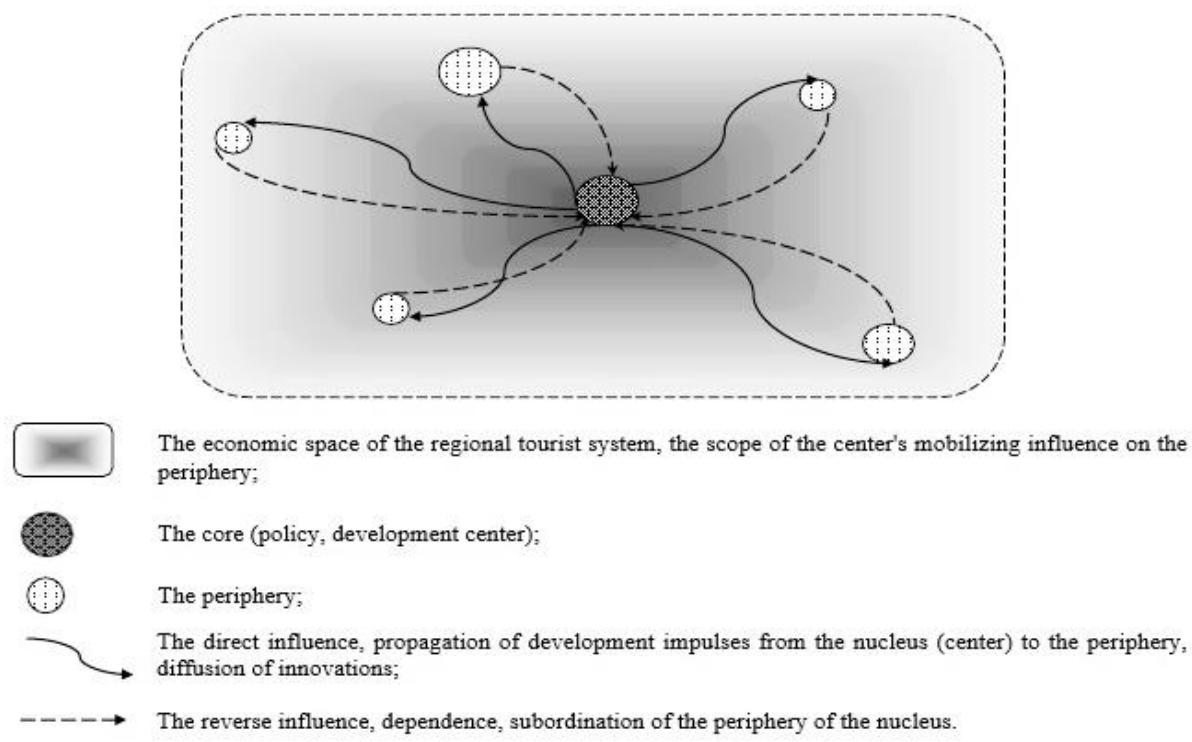

Figure 1. Interaction between the center and the periphery within

the economic space of the regional tourist system (Source: developed by the authors)

Within the framework of the economic environment of the regional tourist system, a scientific and methodological approach to determining the target landmarks for the development of the tourist services market is proposed, which implements polarized tourist space in terms of quantitative and qualitative parameters on the basis of methodological tools, thus enabling:

- analysis of destructive determinants of the periphery and determinantsproducers of the center, by identifying specific threats and risks of the formation of the tourist services market, ensuring the optimal composition of factors that can reduce the gap with the center of the tourist space (regional tourism system) or join its architecture;

-reduction of time spent on structural restructuring of the economic space of the regional system through minimization of the involved tourism resources, intensification and optimization of the positive effect of the defined space;

- assessing the level of the hierarchy of the regional tourist system due to the intensity of the momentum of tourist market development and the nature of innovation diffusion;

- predicting the safe level of functioning of the regional tourist system and identifying clear impulses for the development of the tourist services market, reducing the gap and increasing the powerful impact on the density of interaction of the periphery with the center. 
The scientific and methodological approach that underlies the methodology of spatial polarization of the regional tourist system is recommended to be considered on the basis of 5 stages.

Step 1. Determining the level of the regional tourist system (scale of the tourist services market) to evaluate transformations in the polarized structure of the tourist space at the level of tourist meso-regions (sub-regions).

Step 2. Formation of a system of indicators, which are transformed into indicative parameters of the development of the tourist services market using a multifactor matrix. The first parameter is the intensity of international tourist flows (ITF). The second parameter is an integral indicator of the development of the tourist services market (I), which forms the aggregate value of sub-indices by the following indicators: tourism revenues, tourism contribution to GDP, capital investment in tourism, expenditures related to inland tourism, expenditures concerning inbound tourism.

To bring different indicators of tourist services market development to the integral ones, they need to be normalized - to make the transition from absolute values to normalized values by the formula (Gorina, 2016):

$$
P_{i}=\frac{p_{i}-p_{i(\min )}}{p_{i(\max )}-p_{i(\min )}} \quad \text { Equation } 1
$$

where, $P_{i}$ - is the normalized value of the $i$-th index being analyzed; $p_{i}$ - the value of the $i$-th index being analyzed; $p_{i(\max )}$ and $p_{i(\min )}$ - are respectively the maximum and minimum values of the $\mathrm{i}$-th indicator being analyzed. The integral index is proposed to be determined by the formula (Gorina, 2016):

$$
I=\sum_{i=1}^{m} P_{i} \times \alpha_{i} \quad \text { Equation 2 }
$$

where, $I$ - is an integral indicator of the development of the tourist services market; $m$ the number of indicators analyzed; $P_{i}-$ is the normalized value of the $i$-th indicator being analyzed; $\alpha_{i}$ - is the weight factor of the $i$-th indicator.

Weighting factors equal to one are determined by the expert method.

Stage 3. Increasing the efficiency of the development of the tourist market of the meso-region by increasing the economic results of the tourist entities for each unit of tourism costs for the service of one consumer of the package (voucher). This necessitates the introduction of a unified methodological approach to the polarization of costs and results of tourism activities of local entities, transforming the calculation of economic efficiency from a formal economic procedure into a vital, focused on the specific functioning of tourist operators and travel agencies in the economic space of the regional system.

The tour is a market product, a form of consumption of services, a measure of the realization of the purpose of the trip and at the same time the result of the activity of the tourist enterprise, the source of its profit. The route and the program of measures of life support of consumers is carried out during the journey from the conditions of safety and comfort at registration of tourist services. (Kim \& Bramwell, 2019). In this case, the tour package program represents the cost of tour operators for the services of thirdparty organizations, that is, a list of services provided for safety and comfort in meeting the needs of the consumer: accommodation; transport service; hotel and transport 
reservations; food; transfer (airport pick-up and return to the hotel); excursion service; insurance of tourists; health care; visa services and other expenses related to tourist travel; cultural, entertainment, sports services; service of guides, interpreters and accompanying groups, etc (Voskresenska, 2013).

Given the above conditions, the calculation of tourist costs for the maintenance of one consumer of the package (voucher) is represented by the formula (Voskresenska, 2013):

$$
Q_{t}=\frac{C+P-D(+/-R)}{N+N^{\prime \prime}} \quad \text { Equation } 3
$$

where, $Q_{t}{ }$ - tourist costs for servicing one consumer of a tour package in national currency or conventional currency depending on the direction of the tour: domestic tour - in national currency; foreign - in conventional currency; combined - payments for tourist services within the state are made in national currency, outside it - in conventional currency; $C$ - the main tourist expenses for services under the terms of the tour package; $P$ - profit of the tourist operator; $D$ - discounts provided by the tourist operator to the consumer for certain types of tour package services; $(+/-R)-$ a travel agency commission, where (+) is a mark-up to the price of the tour package, and (-) is a discount given to a travel agency by a travel operator; $N$ - number of tourists in the group; $N^{\prime \prime}$ - number of people accompanying the group on this route.

Step 4. Modeling the development of the tourist services market based on the polarization of the innovative core of the meso- and local levels of the tourist system. This determines the degree of concentration of the trait, which is studied in accordance with the units of the aggregate or in assessing the uneven distribution. As the theory and practice of analyzing the proportionality of the distribution of economic indicators substantiates the relationship of distribution, in particular resources in the economic space of the tourist system (Ruan et al., 2019), so ensuring the proportionality of the innovation core of meso- and local levels streamlines the consistency of the distribution of innovative resources and results of activities of travel operators and travel agencies. At the same time, modeling of development of the tourist services market on a group basis implies the definition of clusters of innovative potential of tourism enterprises. The formalized process of constructing the proportionality models in a generalized form is presented as a correlation between the effective (the volume of tourist services sold in monetary terms) and the factor (cost of resources of innovative potential) features (Belhassen, 2020).

The consistency of proportions is dynamic. Revenues from the sale of tourist services will be marked as $(q)$, the cost of resources of innovative potential $-W$. The share of the cost of the volume of services provided by the i-th enterprise in the total amount will be (Davydova, 2015; Gerasymov et al., 2003; Gorodyskyj, 2007):

$$
d_{q}=\frac{q_{i}}{q} \quad \text { Equation } 4
$$

share of cost of innovative potential resources (Davydova, 2015; Gerasymov et al., 2003; Gorodyskyj, 2007):

$$
d_{W}=\frac{W_{i}}{W}
$$


The ratio of shares of revenue from the sale of services and the cost of resources at enterprises as a coefficient of localization $\left(K_{l o c}\right)$, is calculated by the formula (Davydova, 2015; Gerasymov et al., 2003; Gorodyskyj, 2007):

$$
K_{\text {loc }}=\frac{d_{q}}{d_{W}} \quad \text { Equation } 6
$$

The coefficient of localization $\left(K_{l o c}\right)$ characterizes the ratio of the proportion of the productive trait to the fraction of the factor. If $K_{l o c}<1$, then there is an excess of growth in revenue from the sale of services over the proportional share of the factor trait (cost of resources of innovative potential), and vice versa. That is, the proportionality model consists of two indicators: the proportion of the productive trait $d_{r e s}$ and the proportion of the factor trait $d_{f a c}$. The corresponding localization factor is determined by the formula (Davydova, 2015; Gerasymov et al., 2003; Gorodyskyj, 2007):

$$
K_{\text {loc }}=\frac{d_{\text {res }}}{d_{\text {fac }}} \quad \text { Equation } 7
$$

The localization coefficients distinguish two groups with indicators $K_{l o c<1}$ and $K_{l o c}>1$, i.e. with different and positive values of proportionality of distribution. To determine their effect on the total concentration for each group of indicators, the sums of modules are calculated (Davydova, 2015; Gerasymov et al., 2003; Gorodyskyj, 2007):

$$
D^{-}=\Sigma\left|d_{\text {res }}-d_{f a c}\right| \text { and } D^{+}=\Sigma\left|d_{\text {res }}-d_{f a c}\right| \quad \text { Equation } 8
$$

The indicators characterize the weight of the groups in the formation of both. The indicators characterize the weight of the groups in the formation of both excellent and added distribution characteristics and are used in the development of appropriate management decisions. For the summary characteristic of the proportionality of both distributions, we use the Lorentz concentration curve and, accordingly, the concentration coefficient. Constructing the Lorentz curve: it is calculated using the fraction of signs of resultant $d_{q}$ and factor $d_{W}$. For each group, we calculate $K_{l o c}$; determine the ranks of enterprises by value $K_{l o c}$; build a table of distribution of the enterprise according to the values of ranks $K_{l o c}$; we calculate the series of cumulative values and construct the Lorentz curve on the basis of these values. If the Lorentz curve coincides with the line of uniform distribution, then the shares of the resultant and factor traits coincide. The more the Lorentz curve deviates from the line of uniform distribution, the more the distributions deviate from each other (Davydova, 2015).

The degree of concentration is determined by the concentration coefficient $K_{\text {conc }}$ by the formula (Gerasymov et al., 2003; Gorodyskyj, 2007; Davydova, 2015):

$$
K_{\text {conc }}=\frac{1}{2} \sum\left|d_{y}-d_{x}\right|=\frac{1}{2} \sum\left|d_{q}-d_{W}\right| \quad \text { Equation } 9
$$

If $K_{\text {conc }}=0$ - the distributions are the same; $K_{\text {conc }>1}-$ there are significant 
differences in the distribution. The dynamics of these characteristics allow us to determine the integral indicator of the intensity of revenues from the sale of tourist services and the integral indicator of the intensity of using the innovative potential of tourism enterprises as the cost of aggregate resources.

Step 5. Assessment of the safety level of the regional tourist system (RTS) based on proposed methodological approach that determines and provides spatial distribution of parameters of the aggregate value of subindices integrated into the overall indicator of potential and security threats, guarantees optimal criteria for the functioning of the RTS. At the same time, indicators of threats show the volume and scale of destructive processes and phenomena that increase the instability of RTS.

The mathematical formalization of the calculation of the total security index (S) of the regional tourist system is as follows (Krasavceva, 2014; Mason, 2003):

$$
S_{p}=\sum_{i=1}^{n} \frac{S_{n}-S_{(\min )}}{S_{(\max )}-S_{(\min )}} \quad \text { Equation 10 }
$$

where, $S_{p}$ - is the integral security potential index of RTS; $S_{n}$ - the numerical value of the security potential of RTS; $S_{(\min )}, S_{(\max )}$ - the minimum and maximum values from the corresponding data series; $n$ - number of subindices being studied; $i$ - the essence of the constituent subindices of the regional tourist system. Similarly, the total threat index $(T)$ is calculated by the formula (Krasavceva, 2014; Mason, 2003):

$$
T=\sum_{i=1}^{n} \frac{T_{n}-T_{(\min )}}{T_{(\max )}-T_{(\min )}}
$$

Equation 11

As the security index is interpreted as the difference between integral subindices of potential and security threats of RTS $\left(I_{S}^{t}=S-T\right.$ ), the final formula for calculating the security index of a regional tourist system will be (Krasavceva, 2014; Mason, 2003):

$$
I_{r t s}^{S}=\sum_{i=1}^{n} \frac{S_{n}-S_{(\min )}}{S_{(\max )}-S_{(\min )}}-\sum_{i=1}^{n} \frac{T_{n}-T_{(\min )}}{T_{(\max )}-T_{(\min )}}
$$

Equation 12

On the basis of the formed database, a target model of typification of regional tourist systems of the state is formed, provided that the program objectives are modernized and differentiated within the strategy of development of the tourist services market.

\section{RESULTS AND DISCUSSION}

The complex system of internal and external socio-economic processes of the countries, which generates demand for tourist services, operates in the economic space of different levels with certain thresholds of instability and is extremely sensitive to the effects of destructive factors of different origin. At the same time, the nature of tourism, as a social phenomenon, causes a close interconnection of regional systems at different levels, leading to a significant increase in the spatial intensification of tourist flows (The UNWTO Tourism Dashboard, 2019; Guliyeva et al., 2018; Song \& Lee, 2020). Thus, the time lag of transformational research in the polarized regional tourist system of 20122018 has allowed to rank the markets of tourist meso-regions according to key indicative parameters of the intensity of international tourist flows (ITF) and an integral indicator of 
The Imperatives of the Development of the Tourist Services

Market in Spatial Polarization of the Regional Tourist System

the development of the tourist services market (I). Using the interval scale of ranking, the meso-regions were distributed in the tourist geospace, their place in the service markets was determined and the Center-Periphery model was implemented (Table 1).

Table 1. Hierarchical architecture of tourist meso-regions in the Center-Periphery model, 2012, 2018 *Borderline location in the hierarchical architecture of the regional tourist space of the meso-level

(Source: developed and calculated by the authors (Yefimova \& Grynko, 2015)

\begin{tabular}{|c|c|c|c|c|}
\hline & $2012 \mathrm{p}$. & (I; ITF) & $2018 p$. & (I; ITF) \\
\hline \multirow{8}{*}{ Deep periphery } & \multicolumn{2}{|c|}{$\mathrm{I} \leq 100 ;$ ITF $\leq 25$} & \multicolumn{2}{|c|}{$\mathrm{I} \leq 150 ;$ ITF $\leq 25$} \\
\hline & Central America & $(9.64 ; 6.52)$ & Central America & $(18.44 ; 10.28)$ \\
\hline & South Asia & $(58.8 ; 8.05)$ & Oceania & $(96.89 ; 14.24)$ \\
\hline & Oceania & $(88.64 ; 10.53)$ & North Africa & $(36.79 ; 18.03)$ \\
\hline & North Africa & $(35.51 ; 13.72)$ & Caribbean & $(34.42 ; 23.94)$ \\
\hline & Caribbean & $(28.04 ; 18.94)$ & & \\
\hline & Sahara Desert Region & $(74.26 ; 23.04)$ & & \\
\hline & South America* & $(134.77 ; 18,2)$ & South Asia* & $(108.83 ; 18.27)$ \\
\hline \multirow{3}{*}{$\begin{array}{l}\text { Advanced } \\
\text { periphery }\end{array}$} & \multicolumn{2}{|c|}{$\mathrm{I} \leq 100 ; 25<\mathrm{ITF} \leq 50$} & \multicolumn{2}{|c|}{$100<\mathrm{I} \leq \mathbf{2 0 0} ; \mathbf{2 5}<\mathrm{ITF} \leq \mathbf{5 0}$} \\
\hline & Middle East & $(74.66 ; 39.11)$ & South America & $(172.35 ; 30.77)$ \\
\hline & South-East Asia & $(92.81 ; 49.31)$ & Sahara Desert Region & $(94.68 ; 35.44)$ \\
\hline \multirow{5}{*}{ Semi-periphery } & \multicolumn{2}{|c|}{$100 \leq \mathrm{I} \leq 200 ; 50<$ ITA $\leq 100$} & \multicolumn{2}{|c|}{$100<\mathrm{I} \leq 400 ; 50<$ ITF $\leq 125$} \\
\hline & Northern Europe & $(211.45 ; 52.9)$ & Middle East & $(111.62 ; 53.33)$ \\
\hline & North-East Asia & $(398.32 ; 87.62)$ & Northern Europe & $(242.44 ; 75.95)$ \\
\hline & $\begin{array}{l}\text { Central (Eastern) } \\
\text { Europe }\end{array}$ & $(78$. & South-East Asia & $(180.15 ; 104.63)$ \\
\hline & & & $\begin{array}{l}\text { Central (Eastern) } \\
\text { Europe }\end{array}$ & $(97.89 ; 126.61)$ \\
\hline \multirow{5}{*}{ Center } & \multicolumn{2}{|c|}{$\begin{array}{c}\text { I }>300 ; \text { ITF } \geq 100, \text { a6o ITF } \geq 75, \\
\text { if } I>400\end{array}$} & \multicolumn{2}{|c|}{$\mathrm{I}>300 ; \mathrm{ITF} \geq 125$} \\
\hline & Western Europe & $(372.62 ; 142.7)$ & North-East Asia & $(731.66 ; 142.08)$ \\
\hline & $\begin{array}{l}\text { South (Mediterranean) } \\
\text { Europe }\end{array}$ & $(314.47 ; 158.0)$ & Western Europe & $(397.85 ; 179.95)$ \\
\hline & North America & $(754.84 ; 89.93)$ & South (Mediterranean) & $(335.61 ; 225.21)$ \\
\hline & & & North America & $(905.12 ; 127.58)$ \\
\hline
\end{tabular}

In the hierarchical architecture of the meso-regions of the tourist area of 2012, the deep periphery was formed by the subregions: Central America (international tourist arrivals - 6.2 million people; integral indicator of the development of the tourist services market was equal to 9.64), South Asia (8.05 million people; 58.81), North Africa (13.7 million; 35.51), South America (18.2 million; 134.77), Sahara Desert Region (23.04 million; 74.26), The Caribbean (18.94 million; 28.04) and Oceania (10.53 million; 88.64).

In 2012, South America had a limit value, given the low tourist flows of 18.2 million people for the Advanced periphery and the low level of the integral indicator -134.77 for the deep periphery. In the polarized tourist area the Advanced Periphery was formed by the countries of the Middle East (39.11 million; 74.66), South-East Asia (49.31 million; 92.81), which differed in the unevenness and instability of trends in the market of services.

The Semi-periphery was made up of the sub-regions of Northern Europe (52.9 million; 211.45), North-East Asia (87.62 million; 398.32), Central (Eastern) Europe (87.91 million; 78. 66). The Center for Global Tourist Space, with a significant gap in the number of tourist arrivals and revenues, was formed by the countries of Western Europe (142.7 million; 372.62) and South (Mediterranean) Europe (158.o million; 314.47), which have a diversified market for tourism products and a high intensity of tourist exchanges. North 
Natalia V. TRUSOVA, Yurii Y. KYRYLOV, Viktoriia Hr. HRANOVSKA,

Oleksandr S. PRYSTEMSKYI, Viktoriia M. KRYKUNOVA, Alina Zh. SAKUN

America was ranked in the center of the polarized tourist space, given the unprecedentedly high integral figure (89.93 million; 754.84).

The development of tourist services in the subregions under study in 2018 has undergone changes in the restructuring of the polarized space of the tourist system. Thus, only the countries of Central America (international tourist arrivals - 10.28 million people; 18.44), Oceania (14.24 million; 96.89), North Africa (18.03 million; 36.79) formed the hierarchical level of the Deep Periphery, the Caribbean (23.94 million; 34.42), characterized by low levels of tourism revenue for international tourist arrivals. The boundary between the Deep periphery and the advanced periphery was occupied by South Asia, due to low tourist flows -18.27 million people for the advanced periphery and the low level of the integral indicator -108.83 for the Deep periphery.

The Advanced periphery in 2018 completely changed its structure and was formed by the countries of sub-regions: South America (30.77 million people; 172.35), Sahara Desert Region (35.44 million people; 94.68). The periphery of the tourist area has not undergone any significant changes. The countries of the Middle East (53.33 million; 111.62), Northern Europe (75.95 million; 242.44), South-East Asia (104.63 million; 180.15) are characterized by a rapid increase in their position in the tourism market. The countries of Central (Eastern) Europe show an intensive increase in tourist flows with a modest income from tourism (126.61 million; 97.89). The center of tourist space with a large margin is consistently formed by the countries of Western Europe (179.95 million people; 397.85), South (Mediterranean) Europe (225.21 million people; 335.61).

The countries of the Center are characterized by the generation of tourism innovations, which in the process of spatial diffusion, have rapidly increased tourist flows and mid-region tourism exchanges. It was joined by the countries of North-East Asia (142.07 million; 731.6). Due to the highest value of the integral indicator, the North American subregion was assigned to the World Tourism Area Center with average international tourist arrivals (127.5 million; 905.12).

The structure of the economic space of the regional tourist system of Ukraine for the years 2012-2018 was transformed from the Semi-Periphery to the Advanced Periphery of the tourist services market, due to the inability to form a stable platform for financing and attracting financial resources for introducing innovations (Table 2). According to WTTC, international tourist flows in Ukraine decreased by 47.5 billion USD in 2012-2018. The direct contribution of the tourism sector to the country's GDP is 16.9 billion USD ( 42.8 billion USD in 2018 , or $1.8 \%$ of GDP), indirect contribution 45.3 billion USD ( 115.0 billion USD in 2018 , or $5.7 \%$ of GDP), capital investment in tourism -5 billion USD, internal costs -7 billion USD. Travel expenses increased by 45.5 billion USD. In addition, tourism infrastructure remains uncompetitive compared to the infrastructure of the Central Subregions of the countries of the world.

It should be noted that the greatest impact on the increase in the cost of tourist services in Ukraine has a polarization of income and expenditure of tourism activities of local businesses (Figure 2). Aggregate income from the provision of tourist services (excluding VAT, excise taxes and other mandatory payments) by tourist enterprises of the Black Sea meso-region of Ukraine increased by $2.2 \%$ in $2012-2018$ to 14.23 million USD. The share of legal entities in the formation of total income is $60.6 \%$, of private entrepreneurs $-39.3 \%$, respectively. The increase in profitability from the sale of tourist services is observed in the context of the Odessa and Kherson subregions (1.7 and 4.2 times, respectively). The Mykolayiv subregion has dynamics of decrease of profitability from tourism at the level of $73.5 \%$. Income from excursion activities in the Black Sea meso-region increased by $+51 \%$, its share in the total income from the provision of tourist services is 
3.0\%, with an average value of 0.45 million USD in 2012-2018. The dynamics of change in the income of commissions, agency and other fees in the structure of income from the provision of tourist services (excluding VAT, excise duties and other payments) in the mesoregion increased by $+46 \%$, which equals to an average of 1.54 million USD and constitutes $10.8 \%$ of the aggregate share of the total income (at the expense of the tourist services provided by the entities of the Odessa subregion, the proportion of which is equal to $88.7 \%$ of the subregional indicator). At the same time, there was a clear tendency for increase of operating expenses from tourism activity by $+7.1 \%$, the average value of which was equal to 6.24 million USD, or $43.8 \%$ of the total income in tourism of the subregion.

Table 2. Parameters of the tourist services market in the spatial polarization of the tourist system of Ukraine in 2018 prices, billion USD (Source: Manzo, 2019)

\begin{tabular}{|c|c|c|c|c|c|c|c|c|}
\hline Ukraine & 2012 & 2013 & 2014 & 2015 & 2016 & 2017 & 2018 & $\begin{array}{c}2018 \text { at } \\
2012(+,-)\end{array}$ \\
\hline 1. Visitor exports & $95 \cdot 5$ & 91.0 & 40.6 & 37.7 & 39.3 & 43.7 & 48.0 & -47.5 \\
\hline $\begin{array}{l}\text { 2.Domestic expenditure (includes } \\
\text { government individual spending) }\end{array}$ & 99.2 & 100.5 & $87 \cdot 3$ & 78.8 & 79.5 & 86.7 & 92.2 & -7.0 \\
\hline 3.Internal tourism consumption $(=1+2)$ & 194.8 & 191.5 & 127.9 & 116.5 & 118.8 & 130.4 & 140.0 & -54.8 \\
\hline $\begin{array}{l}\text { 4.Purchases by tourism providers, } \\
\text { including imported goods (supply chain) }\end{array}$ & -135.0 & -131.7 & -89.0 & -81.3 & -82.6 & -90.8 & $-97 \cdot 3$ & +37.7 \\
\hline $\begin{array}{l}\text { 5.Direct contribution of tourism to } \\
\text { GDP }(=3+4)\end{array}$ & 59.7 & 59.8 & 38.9 & 35.2 & 36.2 & 39.6 & 42.8 & -16.9 \\
\hline \multicolumn{9}{|c|}{ Other final impacts (indirect \& induced) } \\
\hline 6. Domestic supply chain & 97.2 & $97 \cdot 3$ & 63.4 & 57.2 & 59.0 & 64.5 & 69.7 & -27.5 \\
\hline 7. Capital investment & 13.4 & 11.5 & 8.7 & 6.9 & 7.2 & 7.9 & 8.4 & -5.0 \\
\hline 8. Government collective spending & 24.0 & 24.0 & 22.6 & 20.7 & 21.8 & 21.9 & 22.1 & -1.9 \\
\hline 9. Imported goods from indirect spending & -11.9 & -9.3 & -9.3 & -10.0 & -10.5 & -11.0 & -11.2 & +0.7 \\
\hline 10. Induced & 37.8 & 39.0 & 26.4 & 22.7 & 23.0 & 24.4 & 26.0 & -11.8 \\
\hline $\begin{array}{l}\text { 11. Total contribution of tourism to } \\
\text { GDP }(=5+6+7+8+9+10)\end{array}$ & 20.0 & 222.4 & 150.7 & 132.7 & $\mid 136.7$ & 147.2 & 157.8 & -62.2 \\
\hline \multicolumn{9}{|c|}{ Employment impacts ('ooo) } \\
\hline 12. Direct contribution of tourism to employmen & 382.9 & 367.0 & 226.0 & 206.6 & 206.7 & 228.1 & 243.0 & -139.9 \\
\hline 13. Total contribution & 1420.4 & 1384.7 & 887.6 & 789.6 & 788.8 & 855.9 & 910.3 & -510.1 \\
\hline \multicolumn{9}{|c|}{ Other indicators } \\
\hline 14. Expenditure on outbound $t$ & 83.1 & 91.1 & $97 \cdot 3$ & 104.3 & 114.1 & $127 \cdot 3$ & 128.6 & $+45 \cdot 5$ \\
\hline
\end{tabular}

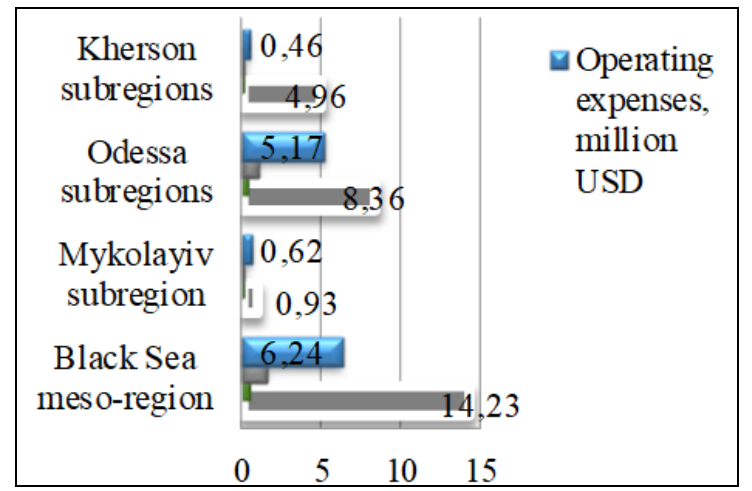

Figure 2. Revenues from the sale of tourist services of local level enterprises in the structure of the Black Sea meso-region of Ukraine for 2012-2018, million USD (Source: Statistical publication of the Regions of Ukraine, 2017; Statistical publication of the Tourism Activity of Ukraine, 2018) 
Natalia V. TRUSOVA, Yurii Y. KYRYLOV, Viktoriia Hr. HRANOVSKA, Oleksandr S. PRYSTEMSKYI, Viktoriia M. KRYKUNOVA, Alina Zh. SAKUN

The polarization of expenditures on the tourist activities of the local level subjects of the Black Sea meso-region of Ukraine is presented in Figure 2.

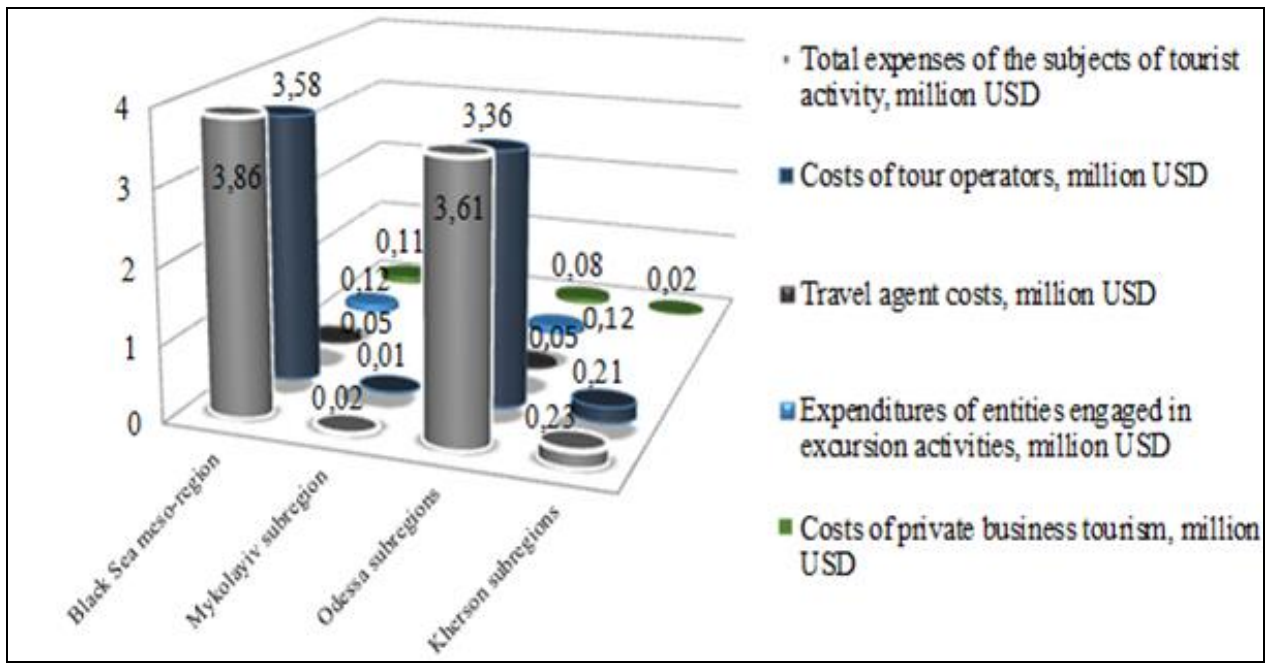

Figure 3. Polarization of expenditures on services of tourist activity of local level entities in the structure of the Black Sea meso-region of Ukraine for 2012-2018, million USD

(Source: calculated by the authors according to the data (Statistical publication of the Regions of Ukraine, 2017; Statistical publication of the Tourism Activity of Ukraine, 2018)

The dynamic trend of spending on tourism services in the Black Sea meso-region tends to reduce total costs by $62 \%$. Such dynamics are characteristic of both the tourist operators of the mesoregion $(-63 \%)$ and tourist agents $(-32 \%)$, whose value was on average at the level of 3.58 and 0.05 million USD. However, such a vector is not inherent in the subjects that carry out excursion activity, their cost, on the contrary, increases by 4.0 times (up to 0.12 million USD). Given the increasing spatial trend of costs from macro-tourism activities (see Table 2), in the meso-regions of Ukraine, expenditures of tourist operators and travel agencies on services used in the production of tourism products increased by an average of 40-95\% in 2012-2018 (Table 3). Differentiation of expenditures of resources used by tourism enterprises in the production of tourism product in the subregions has the largest distribution on accommodation - 59.06\% (177.33 million USD) and transport services - 30.6\% (90.68 million USD).

Modeling the development of the tourist services market based on the polarization of the innovation core of the meso- and local levels of the tourism system of subregions of Ukraine is conditioned by determining the proportionality of the distribution of the value of the aggregate resources of tourism enterprises by the integrated indicators of the intensity of income from the sale of tourist services and the intensity of innovative development (Table 4-5). The last integral indicator is calculated by expert evaluation on the following criteria: enterprise readiness for innovation, enterprise attitude to innovation, innovation intensity, scope of innovation, sufficiency of financing of innovations, information support of innovations, resource support of innovations, results of dissemination of innovations. The most widespread subects in the tourism market of Ukraine are travel agencies (1172 enterprises), which mediate between tour operators and consumers, they are engaged in retail sales of the tourist product; the minimum amount of financial security is 2,000 EUR. Another subject of the tourism market is the 
The Imperatives of the Development of the Tourist Services

Market in Spatial Polarization of the Regional Tourist System

Travel and Excursion Bureau (Travel Bureau, Excursion Bureau), which is the least developed sector of the tourism market, but under certain conditions, these enterprises can intensify the recreational appeal of the subregions of the country. For the study of innovative potential, 24 tourism enterprises were selected (12 travel operators (TOs), 8 travel agents (TAs), 4 travel and excursion bureaus (BESs).

Table 3. Differentiation of expenditures for the consumers of tourist services by subregions of Ukraine on the average for 2012-2018, million USD (Source: Statistical publication of the Regions of Ukraine, 2017; Statistical publication of the Tourism Activity of Ukraine, 2018)

\begin{tabular}{|l|c|c|}
\hline \multicolumn{1}{|c|}{ Indicators } & $\begin{array}{c}\text { Travel } \\
\text { operators }\end{array}$ & $\begin{array}{c}\text { Travel } \\
\text { agencies }\end{array}$ \\
\hline Accommodation costs & 173.14 & 4.19 \\
\hline Food costs & 8.17 & 0.41 \\
\hline Health care costs & 0.82 & 0.07 \\
\hline Excursion service costs (excluding transport services) & 0.83 & - \\
\hline Visa costs (including travel expenses) & 1.00 & 0.05 \\
\hline Costs of transport services & 89.69 & 0.99 \\
\hline $\begin{array}{l}\text { Costs of cultural, educational and leisure services, } \\
\text { cultural organizations }\end{array}$ & 0.48 & 0.04 \\
\hline Costs of other tourist product manufacturing services & 19.06 & 0.38 \\
\hline
\end{tabular}

Table 4. Dynamics of revenue intensity indices from services

of tourism enterprises in spatial polarization of subregions of Ukraine

\begin{tabular}{|c|c|c|c|c|c|c|c|c|}
\hline \multirow[t]{2}{*}{$\begin{array}{c}\text { Tourist } \\
\text { enterprises }\end{array}$} & \multicolumn{4}{|c|}{$\begin{array}{c}\text { Revenue intensity index for } \\
\text { services }\left(I_{r i}\right)\end{array}$} & \multicolumn{4}{|c|}{$\begin{array}{c}\text { Integral indicator of the } \\
\text { intensity of innovation potential } \\
\text { development }\left(I_{i p}\right)\end{array}$} \\
\hline & 2015 & 2016 & $\mathbf{2 0 1 7}$ & 2018 & 2015 & 2016 & $\mathbf{2 0 1 7}$ & 2018 \\
\hline 1 & 2 & 3 & 4 & 5 & 6 & 7 & 8 & 9 \\
\hline TOs №1 & 1.12 & 0.98 & 0.967 & 1.01 & 1.126 & 0.985 & 0.972 & 1.053 \\
\hline TOs №2 & 1.103 & 0.97 & 0.952 & 1.03 & 1.127 & 1.303 & 1.333 & 1.068 \\
\hline TOs №3 & 1.106 & 1.294 & 0.984 & 1.088 & 1.106 & 1.294 & 0.984 & 1.088 \\
\hline TOs №4 & 1.143 & 0.952 & 0.966 & 1.041 & 1.099 & 0.979 & 0.985 & 1.045 \\
\hline TOs №5 & 1.126 & 0.985 & 0.972 & 1.053 & 1.321 & 0.972 & 0.968 & 1.081 \\
\hline TOs №6 & 1.067 & 1.218 & 0.921 & 1.014 & 1.103 & 0.97 & 0.952 & 1.03 \\
\hline TOs №7 & 1.081 & 0.923 & 1.057 & 1.175 & 1.143 & 0.952 & 0.966 & 1.041 \\
\hline TOs №8 & 1.082 & 0.919 & 0.934 & 0.996 & 1.147 & 1.665 & 1.278 & 0.89 \\
\hline TOs №9 & 1.128 & 1.028 & 0.998 & 0.925 & 1.074 & 0.925 & 0.944 & 1.028 \\
\hline TOs №10 & 1.128 & 1.175 & 0.984 & 0.923 & 1.081 & 0.923 & 1.057 & 1.175 \\
\hline TOs №11 & 1.099 & 0.998 & 1.014 & 0.932 & 1.089 & 0.932 & 0.909 & 0.998 \\
\hline TOs №12 & 1.096 & 0.984 & 0.996 & 0.901 & 1.075 & 0.901 & 0.908 & 0.984 \\
\hline TAs №1 & 1.115 & 1.014 & 1.001 & 1.218 & 1.067 & 1.218 & 0.921 & 1.014 \\
\hline TAs №2 & 1.118 & 0.996 & 0.998 & 0.919 & 1.082 & 0.919 & 0.934 & 0.996 \\
\hline TAs №3 & 1.091 & 1.001 & 0.989 & 1.614 & 1.067 & 1.614 & 0.933 & 1.001 \\
\hline TAs №4 & 1.097 & 0.998 & 0.963 & 1.215 & 1.049 & 1.215 & 0.922 & 0.998 \\
\hline TAs №5 & 1.097 & 0.989 & 0.992 & 1.379 & 1.039 & 1.379 & 1.214 & 0.989 \\
\hline TAs №6 & 1.093 & 0.963 & 0.988 & 1.376 & 1.054 & 1.376 & 0.903 & 0.963 \\
\hline TAs No-7 & 1.088 & 0.992 & 1.291 & 1.189 & 1.065 & 1.189 & 0.905 & 0.992 \\
\hline TAs №8 & 1.043 & 0.895 & 0.899 & 1.291 & 1.045 & 0.91 & 0.911 & 0.988 \\
\hline BESs № 1 & 1.065 & 1.291 & 1.298 & 0.895 & 1.043 & 0.895 & 0.899 & 1.291 \\
\hline BESs №2 & 1.045 & 0.953 & 0.951 & 0.859 & 1.026 & 0.859 & 0.903 & 0.953 \\
\hline BESs №3 & 1.043 & 1.298 & 1.029 & 1.026 & 1.021 & 1.12 & 1.066 & 1.298 \\
\hline BESs №4 & 1.026 & 0.859 & 0.903 & 0.953 & 1.011 & 0.831 & 0.857 & 0.951 \\
\hline
\end{tabular}


Natalia V. TRUSOVA, Yurii Y. KYRYLOV, Viktoriia Hr. HRANOVSKA,

Oleksandr S. PRYSTEMSKYI, Viktoriia M. KRYKUNOVA, Alina Zh. SAKUN

We calculate the coefficients of localization and concentration of incomes depending on the intensity of development of innovation potential of tourism enterprises for 2015-2018 (Table 5).

Table 5. Dynamics of coefficients of localization $\left(K_{l o c}\right)$ and concentration of incomes depending on intensity of development of innovative potential of tourist enterprises $\left(K_{\text {conc }}\right)$

\begin{tabular}{|c|c|c|c|c|}
\hline Tourist enterprises & 2015 & 2016 & 2017 & 2018 \\
\hline \multicolumn{5}{|c|}{ Coefficients of localization $\left(K_{l o c}\right)$} \\
\hline TOs № 1 & 1.1076 & 0.94207 & 0.97736 & 1.0889 \\
\hline TOs №2 & 1.02725 & 1.25906 & 1.70162 & 1.08296 \\
\hline TOs №3 & 1.00537 & 0.93729 & 0.98241 & 1.04443 \\
\hline TOs № 4 & 0.96667 & 0.96387 & 0.96346 & 1.04844 \\
\hline TOs № 5 & 1.17948 & 0.92492 & 0.98647 & 1.0722 \\
\hline TOs №6 & 1.03929 & 0.74644 & 0.95042 & 1.06091 \\
\hline TOs №7 & 1.06303 & 0.96674 & 1.07496 & 0.92532 \\
\hline TOs №8 & 1.06577 & 1.69813 & 0.71797 & 0.93328 \\
\hline TOs No99 & 0.95724 & 0.84338 & 1.03861 & 1.16073 \\
\hline TOs №10 & 0.96348 & 0.73627 & 0.91456 & 1.32958 \\
\hline TOs No11 & 0.99622 & 1.09589 & 1.09589 & 1.11839 \\
\hline TOs №12 & 0.98611 & 0.85823 & 1.07762 & 1.15687 \\
\hline TAs № 1 & 0.96209 & 1.12585 & 1.06774 & 0.8695 \\
\hline TAs №2 & 0.973 & 0.86483 & 1.04973 & 1.13194 \\
\hline TAs №3 & 0.98326 & 1.51127 & 1.04138 & 0.64775 \\
\hline TAs № 4 & 0.96138 & 1.14109 & 1.0261 & 0.85789 \\
\hline TAs №5 & 0.95222 & 1.30689 & 0.80276 & 0.74905 \\
\hline TAs №6 & 0.9695 & 1.33926 & 1.07488 & 0.73095 \\
\hline TAs No-7 & 0.98412 & 1.12342 & 1.40143 & 0.87138 \\
\hline TAs №8 & 1.0073 & 0.953 & 0.96947 & 0.7993 \\
\hline BESs №1 & 0.9846 & 0.64978 & 1.01843 & 1.50655 \\
\hline BESs №2 & 0.98709 & 0.84484 & 1.03463 & 1.15872 \\
\hline BESs №3 & 0.98417 & 0.80875 & 0.94831 & 1.32132 \\
\hline BESs №4 & 0.99067 & 0.90673 & 1.03514 & 1.04224 \\
\hline \multicolumn{5}{|c|}{$\begin{array}{l}\text { Concentration of incomes depending on intensity } \\
\text { of development of innovative potential of tourist enterprises }\left(K_{\text {conc }}\right)\end{array}$} \\
\hline$K_{\text {conc }}$ & 0.138701 & 0.811138 & 0.055302 & 0.690402 \\
\hline
\end{tabular}

The presented calculations indicate a low concentration of revenues from the sale of services in the spatial polarization of the innovation core of tourism enterprises and the intensity of the latter. Accordingly, there is a need to introduce a comprehensive approach to assessing the concentration of the aggregate parameters of ensuring a safe level of functioning of the tourist system, which is differentiated by the components of the regional potential of security and threats, guarantees the development of the tourist services market and modifies the tourist system on the meso-level as a whole (Table 6, Figure 4).

The relative homogeneity of groups of subregions that have the same differential of the security indices and which are adjacent to the city of Kiev is proposed to be identified as macro-regions. Thus, the Type I macro-region (Western) is characterized by the lowest level of threats of the safe level of RTS and is the second in Ukraine after Kiev by the value of the general index (Figure 5). The Central macro-region (Type II) contains the largest number of subregions and only the Type IV (Eastern) macro-region 
is ahead of the RTS Security Index. Type III macro-region (Southern), despite its maritime location, is characterized by averages of all calculated indices. The Eastern macro-region has the lowest security potential of RTS and a fairly high level of threats and, as a consequence, the lowest in Ukraine in the overall index.

Table 6. Typology of components of a secure level of the regional tourist system of Ukraine

\begin{tabular}{|c|c|c|}
\hline $\begin{array}{l}\text { RTS security } \\
\text { components }\end{array}$ & RTS security potential subindices $\left(n_{i}\right)$ & RTS subindexes of threats $\left(t_{i}\right)$ \\
\hline Political & $\begin{array}{l}\mathrm{n}_{1}-\text { the presence of a common border with } \\
\text { EU countries; }\end{array}$ & $\begin{array}{l}\mathrm{t}_{1}-\text { the presence of a common } \\
\text { border with the the Russian } \\
\text { Federation; } \mathrm{t}_{2}-\text { proximity to areas of } \\
\text { military and political conflict; }\end{array}$ \\
\hline Social & $\begin{array}{l}\mathrm{n}_{2}-\text { number of cultural monuments; } \\
\mathrm{n}_{3}-\text { proportion of persons with higher } \\
\text { education in the population; } \\
\mathrm{n}_{4}-\text { share of Ukrainians among the population; } \\
\mathrm{n}_{5}-\text { number of foreigners served in } \\
\text { collective accommodation facilities; } \\
\mathrm{n}_{6}-\text { the share of the population of the region } \\
\text { aged } 25-34 \text {; } \\
\mathrm{n}_{7}-\text { number of university graduates in } \\
\text { tourism specialties; } \\
\mathrm{n}_{8}-\text { the level of income of the population; }\end{array}$ & $\begin{array}{l}t_{3}-\text { index of corruption in the } \\
\text { region; } \\
t_{4}-\text { unemployment rate; } \\
t_{5}-\text { number of crimes against } \\
\text { public safety, order and morality; } \\
t_{6}-\text { number of crimes against } \\
\text { property; }\end{array}$ \\
\hline Economical & $\begin{array}{l}\mathrm{n}_{9}-\text { investments in hotel and restaurant business; } \\
\mathrm{n}_{10}-\text { number of tourist subjects } \\
\text { activities (tour operators and travel agents); } \\
\mathrm{n}_{11}-\text { revenues from the provision of tourist } \\
\text { services; }\end{array}$ & \\
\hline Ecological & $\begin{array}{l}n_{12}-\text { share of nature reserves in the area of } \\
\text { the region; }\end{array}$ & $\begin{array}{l}\mathrm{t}_{7}-\text { the amount of pollutant emissions } \\
\text { substances in the atmospheric air; } \\
\text { t8 - the volume of waste generation } \\
\text { I-III hazard classes; }\end{array}$ \\
\hline Informational & $\begin{array}{l}\mathrm{n}_{13}-\text { the region's share of the nationwide } \\
\text { Internet audience; } \mathrm{n}_{15}-\text { number of tourism- } \\
\text { related websites. }\end{array}$ & \\
\hline
\end{tabular}

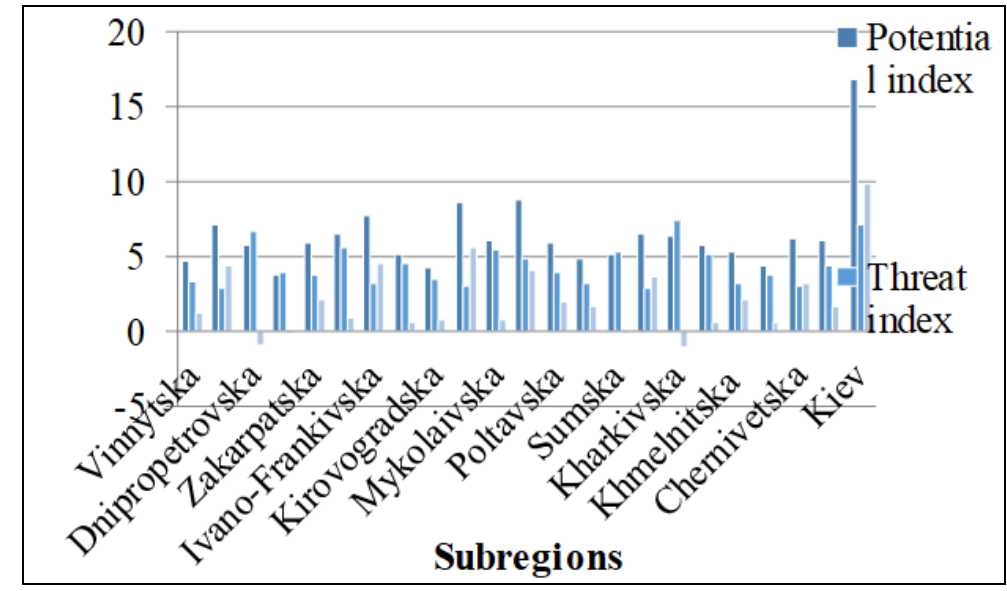

Figure 4. Differentiation of RTS security and threat indices in subregions of Ukraine 
Natalia V. TRUSOVA, Yurii Y. KYRYLOV, Viktoriia Hr. HRANOVSKA, Oleksandr S. PRYSTEMSKYI, Viktoriia M. KRYKUNOVA, Alina Zh. SAKUN

In the distribution of factor loadings by the security potential indexes (ni) and threats of RTS (ti), it is revealed that the first factors have the highest values of the subindices with intensive development of the tourist services market, first of all, on the basis of large tourist centers. Indirectly, this aspect of the influence of the first factor may be related to the processes of urbanization of subregional centers with a population close to one million and in the city of Kiev. The load of the second factor is more spatial than the structural and functional embodiment. This factor is related to the geopolitical location of megacities and their proximity to areas of military and political conflict.

At the present stage, the second factor can be interpreted in the context of political and social threats to the security of RTS. At the same time, the second factor demonstrates a clear polarization along the west-east axis and is most pronounced in the Western macro-region of Ukraine, in particular in the subregions characterized by the highest share of Ukrainians among the population and bordering EU countries.

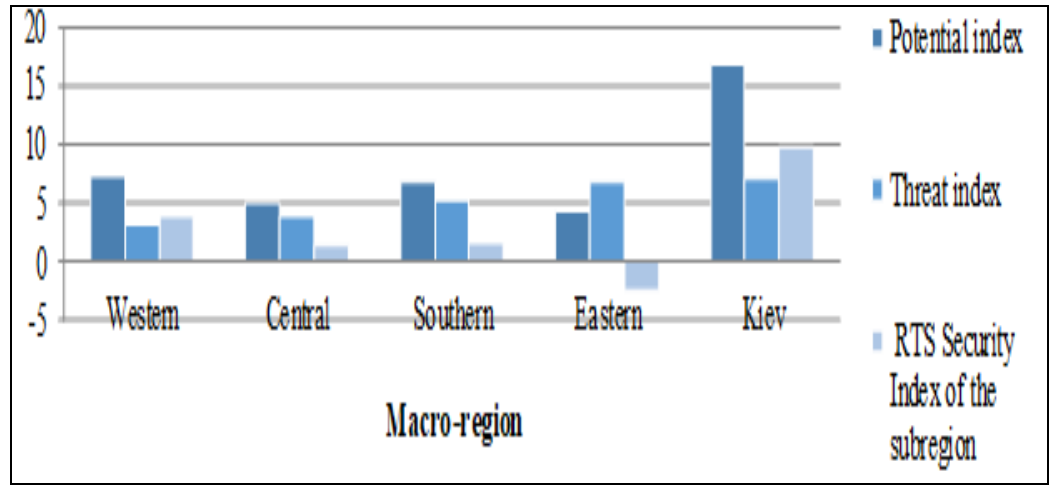

Figure 5. Differentiation of RTS security indices in macro-regions of Ukraine

The results of the study indicate a significant differentiation of the safety indices of the regional tourist system of the macro level, taking into account the acceleration of the rate of change of its functioning parameters, with a steady increase in competition. In this regard, we believe that in the process of developing and implementing strategic and program goals for the modernization of the tourist market in the Ukrainian market, it is necessary to take into account the regional differences.

\section{CONCLUSIONS}

Strengthening Ukraine's position in the tourist market is possible under the conditions of creation of a national competitive tourist product, image of macro-regions (meso-regions, subregions), adoption of an early strategy and implementation of sustainable development policy for solving urgent problems of ensuring the stay of foreign citizens; the use of information technology to promote the tourism product, meet the needs of consumers; improvement of management and marketing of foreign economic activity in tourism; improving national transport links and roads; implementation of the principles of corporate social responsibility in the tourism business; procurement of environmentally friendly products and green building development; responsibility for natural resources; the protection of terrestrial ecosystems, the rational use of forests and the cessation of biodiversity loss.

Creating a strategic management system to ensure a secure level and competitiveness of the regional tourist system will allow the most complete satisfaction of 
The Imperatives of the Development of the Tourist Services

Market in Spatial Polarization of the Regional Tourist System

the needs of the target markets, increase the level of consumption of tourist services. Only a well-designed and consistently implemented strategy can counteract constant dumping, falling solvent demand, declining real income, and profit in tourism businesses.

\section{REFERENCES}

Aleksushin, G.V., Ivanova, N.V. \& Solomina, I.J. (2020). The use of technology of digital economy to create and promote innovative excursion products. Advances in Intelligent Systems and Computing, 908, 404-410.

Belhassen, Y. (2020). Metaphors and tourism paradoxes. Tourism Management, 79, Article number 104095.

Brailly, J. (2016). Dynamics of networks in trade fairs-a multilevel relational approach to the cooperation among competitors. Journal of Economic Geography, 16(6), 1279-1301.

Brandão, F., Breda, Z. \& Costa, C. (2019). Innovation and internationalization as development strategies for coastal tourism destinations: The role of organizational networks. Journal of Hospitality and Tourism Management, 41, 219-230.

Brozovic, D. (2020). Business model based on strong sustainability: Insights from an empirical study. Business Strategy and the Environment, 29(2), 763-778.

Çakmak, E., Lie, R. \& Selwyn, T. (2019). Informal tourism entrepreneurs' capital usage and conversion. Current Issues in Tourism, 22(18), 2250-2265.

Cano Guervos, R.A., Frías Jamilena, D.M., Polo Peña, A.I. \& Chica Olmo, J. (2020). Influence of tourist geographical context on customer-based destination brand equity: an empirical analysis. Journal of Travel Research, 59(1), 107-119

Chen, C.M. \& Zeng, D.-Z. (2018). Mobile capital, variable elasticity of substitution, and trade liberalization. Journal of Economic Geography, 18(2/1), 461-494.

Chi, H.-K., Huang, K.-C. \& Nguyen, H.M. (2020). Elements of destination brand equity and destination familiarity regarding travel intention. Journal of Retailing and Consumer Services, 52, Article number 101728.

Cosenz, F., Rodrigues, V.P. \& Rosati, F. (2020). Dynamic business modeling for sustainability: Exploring a system dynamics perspective to develop sustainable business models. Business Strategy and the Environment, 29(2), 651-664.

Davydova, O. (2015). Features of application of innovations in development of tourist industry of Ukraine. Bulletin of Taras Shevchenko National University of Kyiv, 7(172), 65-69.

Gorban, G.P. (2017). Concept of formation and management of tourism services market development in conditions of spatial polarization. Investment: Practice and Experience, 2, 16-21.

Gerasymov, V.V., Mynyna, L.S., \& Vasylev, A.V. (2003). Management of innovative potential of production systems. Novosibirsk: NGASU.

Gorina, G.O. (2016). Factors of formation of spatial polarization of socio-economic development of regions. Bulletin of the Khmelnytsky National University, Series "Economic Sciences", 4, 187-191.

Gorodyskyj, T.I.(2007). Innovation and investment potential: factors of influence. Scientific Bulletin of the Lviv Polytechnic National University, 17(2), 276-284.

Guliyeva, A., Britchenko, I. \& Rzayeva, U. (2018). Global security and economic asymmetry: a comparison of developed and developing countries. Journal of Security and Sustainability Issues, 7(4), 707-718.

Guryanova, L.S. \& Prokopovich, S.V. (2013). Models for assessing the impact of interregional interaction on the processes of convergence of territorial development. Business Inform, 1, 62-67.

Khalid, U., Okafor, L.E. \& Shafiullah, M. (2020). The effects of economic and financial crises on international tourist flows: a cross-country analysis. Journal of Travel Research, 59(2), 315-334.

Kim, S. \& Bramwell, B. (2019). Boundaries and boundary crossing in tourism: A study of policy work for tourism and urban regeneration. Tourism Management, 75, 78-89.

Kisswani, K.M., Zaitouni, M. \& Moufakkir, O. (2020). An examination of the asymmetric effect of oil prices on tourism receipts. Current Issues in Tourism, 23(4), 500-522.

Kocziszky, G. Nagy, Z., Tóth, G. \& Dávid L. (2015). New method for analysing the spatial structure of Europe. Economic Computation and Economic Cybernetics Studies and Research, 49(3), 143-160.

Krasavceva, L.Yu. (2014). Geospatial structures of the tourist market as a result of territorial differentiation of the tourist process. Investments: Practice and Experience, 15, 145-148.

Lohmatov, A.S. (2011). Analysis of factors of tourism development in the region. Bulletin of the V. Dahl East Ukrainian National University, 7(161), 86-98.

Mason, P. (2003). Tourism impacts, planning and management. Butterworth-Heinemann: Elsevier Linacre House. 
Majewska, J. \& Truskolaski, S. (2019). Cluster-mapping procedure for tourism regions based on geostatistics and fuzzy clustering: example of Polish districts. Current Issues in Tourism, 22(19), 2365-2385.

Maltseva, L.Yu. (2016). On the issue of asymmetry of territorial development in the conditions of spatial transformation of the economy. Society: Politics, Economics, Law, 5. http://domhors.ru/rus/files/arhiv_zhurnala/pep/2016/5/economics/maltseva.pdf

Manzo, G.G. (2019). Oxford Economics for World Travel \& Tourism Council. Economic impact 2019 Ukraine. https://www.wttc.org/-/media/files/reports/economic-impact-research/regions-2019/world2019.pdf.

Mitrofanov, A.V. (2013). The unity of the economic space: approaches to the interpretation and content of the concept. Bulletin of Penza State University, 2, 46-52.

Moiseeva, N.I. \& Didenko, D.F. (2018). Genesis and peculiarities of formation of regional market of tourist services. Actual Problems of Innovative Economics Scientific Journal, 4, 83-88.

Partridge, M.D., Rickman, D.S., Olfert, M.R., \& Tan, Y. (2017). International trade and local labor markets: Do foreign and domestic shocks affect regions differently? Journal of Economic Geography, 17(2), 375-409.

Ruan, W., Li, Y., Zhang, S. \& Liu, C.-H. (2019). Evaluation and drive mechanism of tourism ecological security based on the DPSIR-DEA model. Tourism Management, 75, 609-625.

Serrano, L., Sianes, A. \& Ariza-Montes, A. (2019). Using bibliometric methods to shed light on the concept of sustainable tourism. Sustainability, 11(24), Article number 6964.

Shablyj, O. \& Soxaczka, G. (2012). Categories of centrality and periphery in general and descriptive social geography: history of Ukrainian geography. All-Ukrainian Scientific-Theoretical Journal, 26, 7-15.

Song, S. \& Lee, S. (2020). Motivation of internationalization and a moderating role of environmental conditions in the hospitality industry. Tourism Management, 78, Article number 104050, https://doi.org/ 10.1016/j.tourman.2019.104050.

Spalding, M. \& Parrett, C.L. (2019). Global patterns in mangrove recreation and tourism. Marine Policy, 110, Article number 103540, 10.1016/j.marpol.2019.103540.

Timmer, M.P., Miroudot, S. \& De Vries, G.J. (2019). Functional specialisation in trade. Journal of Economic Geography, 19(1), 1-30.

Tolstoguzov, O.V. (2012). Region in the context of globalization: spatial and institutional aspects. Transactions of Karelian Research Center of Russian Academy of Science, 6, 20-29.

Voskresenska, O.Ye. (2013). Costs and efficiency of activity of subjects of tourist business of Ukraine. Economic Innovation, 54, 43-48.

Wood, S., Wrigley, N. \& Coe, N.M. (2017). Capital discipline and financial market relations in retail globalization: Insights from the case of TESCO plc. Journal of Economic Geography, 17(1), 31-57.

Yefimova, S.A. \& Grynko, T.V. (2015). Methodical approaches to assessing the innovation potential of a service industry enterprise. Bulletin of Dnipropetrovsk University. Innovation Management Series, 5, 30-37.

Zarezadeh, Z., Benckendorff, P. \& Gretzel, U. (2019). Lack of progress in tourist information search research: a critique of citation behaviour and knowledge development. Current Issues in Tourism, 22(19), 2415-2429.

*** Statistical publication of the Regions of Ukraine. (2018). Kyiv: State Statistics Service of Ukraine. http://www.ukrstat.gov.ua/druk/publicat/kat_u/2018/zb/11/zb_ru1ch2018.pdf.

*** Statistical publication of the Tourism Activity of Ukraine. (2017). Kyiv: State Statistics Service of Ukraine. http://www.ukrstat.gov.ua/druk/publicat/kat_u/2018/zb/o5/zb_td_2017.pdf

*** The UNWTO Tourism Dashboard. (2019). Insights on key performance indicators for inbound and outbound tourism at the global, regional and national levels. https://www.unwto.org/unwto-tourism-dashboard.

Submitted:

11.02.2020
Revised:

14.04.2020
Accepted and published online 21.04.2020 